\title{
Analisis Kinerja Pemasaran PT. NSS
}

\author{
Edwin Kanadi \\ email: edwinkanadi@outlook.com \\ M.Y. Dwi Hayu Agustini \\ email: mariaagustini84@yahoo.com \\ Program Pascasarjana Manajemen, Fakultas Ekonomi Dan Bisnis \\ Universitas Katolik Soegijapranata
}

\begin{abstract}
NSS Limited Liability Company (NSS LLC) is a lubricant product distributor which has distribution permit from principal of a certain area. The company should maintain a certain performance as the principal's criteria. Effort to maintain company's marketing performance always should be conducted sothat to hold the distribution permit. This research aimed to analyze the marketing performance of NSS LLC based on 4Ps elements of marketing mix. Data were collected from 50 active consumers which routinely purchase in six month lately with questionnaires. Desciptive analyze was used to depict the company's marketing performance with tables and using average. Overall, results showed that NSS LLC's marketing performance were good. Each marketing mix element was scored good by consumers. Place distribution element was scored the best compared to other elements, especially related to product guarentee to reach the consumers' hands in good condition and on exact time. Whilst promotion as the marketing mix element was scored the lowest, though promotion programs were scored interesting and frequently conducted.
\end{abstract}

Keywords: 4 Ps, principal, main distributor, marketing performance.

\section{LATAR BELAKANG}

PT. NSS adalah distributor utama produk pelumas di suatu area yang telah ditetapkan. Sebagai distributor, perusahaan harus mengikuti ketentuan-ketentuan yang ditetapkan oleh principal.Perusahaanwajib membeli produk dalam kuantitas tertentu dari principaldan menjualnya dalam batasan harga yang sudah ditetapkan oleh principal. Terkait dengan kewajiban ini, perusahaan diberi kebebasan untuk menyalurkan produkkepada konsumen yang dipandang sesuai tetapi tanpa melanggar batas teritorial distributor yang telah ditetapkan dan dalam upaya untuk dapat mencapai target kuantitas yang ditetapkan. Perusahaan juga diberi kebebasanuntuk melakukan kegiatan promosi sejauh sesuai dengan dukungan 
anggaran yang diberikan oleh principal. Kelebihan biaya yang timbul akan dibebankan pada perusahaan.

Secara berkala, perusahaan melakukan reviewterhadap kinerja perusahaan yang diukur dari pertumbuhan penjualan perusahaan. Reviewini dilakukan untuk mengevaluasi kinerja dalam upaya untuk dapat memenuhi ketentuan yang ditetapkan principal dan juga mencapai tujuan perusahaan.

Dalam upaya untuk mencapai tujuan tersebut, beberapa upaya dilakukan oleh perusahaan, seperti melakukan promosi penjualan. Promosi penjualan merupakan salah satu bentuk promosi yang paling dikenal dan paling banyak digunakan dalam bidang distribusi. Namun demikian, perusahaan masih menghadapi masalah peningkatan penjualan yang belum signifikan. Penjualan perusahaan justru mengalami penurunan sebesar $4,8 \%$ pada semester pertama 2017 dibanding periode yang sama pada 2016 (PT. NSS, 2017).

Tingkat persaingan dalam penjualan pelumas menuntutperusahaan untuk selalu melakukan upaya-upaya strategis gunamencapai tingkat pertumbuhan penjualan yang ditargetkan, yaitu sebesar 5\% per tahun.Perusahaan harus berusaha untuk merebut pasar dengan berbagai strategi pemasaran yang mampu meningkatkan kepuasan konsumen secara optimal sehingga konsumen akan memiliki komitmen yang kuat untuk kembali membeli produk di masa yang akan datang.

Menurut Kotler (2001), tujuan pemasaran perusahaan dapat dicapai melalui strategi bauran pemasaran. Strategi yang baik adalah strategi yang mampu mencapai tujuan perusahaan dan tujuan konsumen. Oleh karena itu, perlu diketahui apakah strategi pemasaran yang telah dilakukan perusahaan sudah dinilai baik oleh konsumen. Berdasarkan penilaian tersebut, penelitianini dimaksudkan untuk mengetahui bagaimana strategi pemasaran yang dijalankan PT. NSS menurut penilaian konsumen. Penilaian ini akan menunjukkan kinerja pemasaran perusahaan sehingga hasilnya dapat digunakan sebagai dasar perbaikan strategi di masa datang sehingga tujuan perusahaan dapat dicapai dengan cara lebih efektif. 


\section{LANDASAN TEORI}

Pemasaran adalah sebuah proses dimana individu dan kelompok dapat mendapatkan apa yang mereka inginkan dengan membeli produk(Kotler, 2001). Hal ini dapat dicapai dari proses yang terjadi antara perusahaan dan konsumen. Tentang hal iniJaakkola et al (2012)menjelaskan pemasaran sebagai aktivitas, rangkaian institusi, dan proses untuk menciptakan, mengkomunikasikan, menyampaikan, dan bertukar penawaran yang bernilai bagi pelanggan, klien, mitra, dan masyarakat pada umumnya. Proses tersebut harus diciptakan secara sistematis dalam bentuk rencana-rencana yang akan dilakukan untuk mencapai tujuan perusahaan secara efektif. Rencana atau langkah yang harus dilakukan oleh perusahaan untuk mencapai suatu tujuan yang diharapkan disebut sebagai strategi.

Strategi pemasaran memberikan deskripsi yang jelas mengenai apa yang dilakukan perusahaan untuk mencapai tujuan pemasarannya (Kotler, 2001). Mongay (2006)menyatakan bahwa strategi pemasaran adalah sebuah komitmen, bukan suatu tindakan. Hal penting yang perlu diperhatikan dalam strategi pemasaran adalah variabel yang dapat dikontrol dan yang tidak dapat dikontrol (Triana, 1985). Salah satu variabel yang dapat dikontrol oleh perusahaan adalah bauran pemasaran, yang merupakan kombinasi dari berbagai variabel pemasaran yang dapat dikendalikan oleh perusahaan untuk menghasilkan respon penjualan yang diinginkan, sehingga akan mencapai volume penjualan dengan biaya yang memungkinkan, untuk mencapai tingkat keuntungan yang diinginkan (Kotler, 2001).

Bauran pemasaran mencakup empat elemen atau 4P, yaitu product (produk), price (harga), promotion (promosi), dan place (distribusi). Keempat elemen ini saling berkaitan satu sama lainsebagai sebuah strategi yang terintegrasi untuk mencapai tujuan perusahaan.Selamabertahun-tahun4P telah digunakan sebagai dasar dalam pembuatan rencana pemasaran (Vignali, 2001).

Produk merupakan sesuatu yang ditawarkan kepada konsumen untuk diperhatikan, dimiliki, digunakan, atau dikonsumsi yang bisa memuaskan keinginan dan kebutuhan konsumen. Karakteristik produk merupakan cara yang 
kompetitif untuk membedakan produk perusahaan dengan produk pesaing. Bagi konsumen, produk dapat ditinjau dari atribut produk, seperti prestise, kualitas, harga, bentuk atau penampilan, disain, dan fungsi.

Harga adalah barang yang dibebankan untuk suatu produk atau jasa. Secara lebih luas, harga adalah keuntungan keseluruhan yang ditukar oleh konsumen untuk mendapatkan keuntungan dari produk atau layanan. Persaingan penetapan harga dan harga merupakan hal utama bagi perusahaan.

Produk harus dipromosikan ke publik. Promosi merupakan upaya untuk menginformasikan atau menawarkan produk atau layanan dengan tujuan menarik calon konsumen untuk membeli atau mengonsumsinya. Untuk mengkomunikasikan produk dengan baik, strategi bauran promosi dapat disiapkan. Bauran promosi terdiri dari lima komponen utama (periklanan, promosi penjualan, promosi personal, penjualan langsung, dan hubungan publik) yang dapat dikombinasikan untuk mencapai tujuan komunikasiyang terbaik.

Distribusi adalah proses pengiriman barang atau jasa dari produsen ke konsumen dan pengguna, kapan dan dimana barang atau jasa tersebut diperlukan. Proses distribusi pada dasarnya menciptakan kegunaan waktu, tempat, dan transfer properti. Perusahaandapat menggunakan perantara pemasaran untuk memasarkan produk atau memasarkan sendiri produknya secara langsung kepada konsumen yang memungkinkan produk tersedia untuk digunakan atau dikonsumsi oleh konsumen atau pengguna industri.

Menurut Amna (2014)penerapan strategi bauran tersebut akan membantu kelangsungan hidup perusahaan. Hal ini sesuai dengan hasil penelitian Wibowo, Arifin, dan Sunarti (2015)yang melakukan analisis tentang efektivitas strategi pemasaran, yaitu bahwa strategi pemasaran dalam menghadapi persaingan antar perusahaan batik mampu meningkatkan total penjualan dari tahun ke tahun.

Tingkat kepentingan masing-masing elemen berbeda tergantung pada industri dan produk. Dalamstudinya, Fayshal dan Medyawati (2013) menyimpulkan bahwa promosi lebih mendapatkan prioritas dibandingkan dengan 
aspek bauran pemasaran lainnya pada kasus AJB Bumi Putera Syariah yang menerapkan strategi bauran pemasaran.

\section{METODE PENELITIAN}

\section{PopulasidanSampel}

Populasi dalam penelitian ini adalah konsumen PT. NSS yangmerupakan outletyang menjual kembali produk ke konsumen akhir yang jumlahnya 100 outlet. Sampel adalah sebagian dari konsumen PT. NSS.Dengan teknik purposive sampling, sampelyang diambil adalah konsumen aktif, yaitu konsumen yang melakukan pembelian secara rutin dalam6 bulan terakhir.Konsumen tersebut dianggap mampu untuk memberikan respons yang lebih akurat dibandingkan dengan konsumen yang pasif. Jumlah konsumen aktif ada sebanyak 50 outlet.

\section{MetodePengumpulan Data}

Data dikumpulkan denganmetode kuesioner (Sugiyono, 2014).Kuesioner berisi pernyataan-pernyataan tentang tiap elemen bauran pemasaran dan responden diminta memberikan penilaiannya dengan menggunakan lima-skala Likertyang berkisar dari $1=$ sangat tidak setuju hingga $5=$ sangat setuju. Sedangkan pendapat responden tentang alasan memberikan penilaian tersebut ditanyakan delam bentuk pertanyaan terbuka.

Kuesioner didistribusikan kepada pemilik outlet yang menjadi sampel. Pemilik outlet dihubungi melalui telepon untuk menanyakan kesediaannya untuk berpartisipasi dalam penelitian dan kemudian disepakati waktu pengisian kuesioner dengan pemilik yang bersedia berpartisipasi.

Dilakukan uji validitas dan reliabilitas sebelum kuesioner didistribusikan kepada responden untuk memastikan keakuatan kuesioner dalam melakukan fungsi ukurnya (Azwar, 2000).Suatu instrumen yang valid menunjukkan kemampuan mengukur apa yang ingin diukur. Uji validitas dilakukan dengan korelasiProductMoment. Suatu instrumen dikatakan valid bila nilai $\mathrm{r}$ hitung $>\mathrm{r}$ tabel dan sebaliknya tidak valid bila $r$ hitung $<\mathrm{r}$ tabel (Ghozali, 2013). Hasil uji 
validitas (tabel 1) menunjukkan bahwa semua item pernyataan dalam kuesioner adalah valid.

Tabel 1. Hasil Uji Validitas

\begin{tabular}{lccc}
\hline \multicolumn{1}{c}{ Pernyataan } & r hitung & r tabel & Keterangan \\
\hline \hline Jenis produk lengkap & 0.447 & 0.279 & Valid \\
\hline Semua jenis produk tersedia & 0.447 & 0.279 & Valid \\
\hline Harga yang ditawarkan kompetitif & 0.415 & 0.279 & Valid \\
\hline Tempo pembayaran piutang dagang cukup & 0.415 & 0.279 & Valid \\
\hline Program promosi menarik & 0.818 & 0.279 & Valid \\
\hline Program promosi sering dilakukan & 0.818 & 0.279 & Valid \\
\hline Pengiriman barang tepat waktu & 0.357 & 0.279 & Valid \\
\hline Produk yang diterima konsumen terjamin baik & 0.357 & 0.279 & Valid \\
\hline
\end{tabular}

Sumber: Data Primer yang Diolah

Reliabilitas menunjukkan sejauh mana hasil suatu pengukuran dapat dipercaya. Secara empirik, tinggi rendahnya reliabilitas ditunjukkan oleh koefisien reliabilitas yang dihitung dengan Cronbach's Alpha. Bila koefisien Cronbach's Alpha > 0,6 maka instrumen adalah reliabel. Hasil uji reliabilitas (tabel 2) menunjukkan bahwa instrumen adalah reliabel dan karenanya kuesioner dapat digunakan untuk mengumpulkan data.

Tabel 2. Hasil Uji Reliabilitas

\begin{tabular}{lcc}
\hline Variabel & Cronbach's Alpha & Keterangan \\
\hline \hline Produk & 0.618 & Reliabel \\
\hline Price & 0.655 & Reliabel \\
\hline Place & 0.650 & Reliabel \\
\hline Promotion & 0.898 & Reliabel \\
\hline
\end{tabular}

Sumber: Data Primer yang Diolah 


\section{MetodeAnalisis Data}

Metode analisis deskriptif kualitatif digunakan untuk mengolah data yang diperoleh dari kuesioner. metode analisis deskriptif kualitatif adalah metode yang digunakan dengan menganalisis dan mendeskripsikan keadaan dari suatu objek yang akan diteliti(Ghozali, 2013). Penilaian responden dari setiap elemen bauran pemasaran akan dideskripsikan dengan menggunakan bantuan tabel untuk menunjukkan nilai rata-rata tiap elemen bauran pemasaran. Interpretasi dari nilai rata-rata dilakukan dengan menggunakan kelas interval sebagai berikut:

$$
\text { Rentang skala }=\frac{\text { nilai maksimum }- \text { nilai minimum }}{\text { jumlah kelas }}=\frac{5-1}{5}=\frac{4}{5}=0,8
$$

\begin{tabular}{ll}
\hline Kelas Interval & Kategori \\
\hline \hline $1,00-1,80$ & Sangat tidak setuju \\
\hline $1,81-2,60$ & Tidak setuju \\
\hline $2,61-3,40$ & Netral \\
\hline $3,41-4,20$ & Setuju \\
\hline $4,21-5,00$ & Sangat setuju \\
\hline
\end{tabular}

Penilaian responden terhadap tiap elemen bauran pemasaran ini kemudian dikonfirmasikan berdasar alasan yang dikemukakan atas penilaian terhadap elemen yang bersangkutan. Alasan responden ditampilkan dalam tabel frekuensi untuk menunjukkan intensi alasan.

\section{HASIL DAN PEMBAHASAN}

\section{GambaranUmum Perusahaan}

PT. NSS merupakan anak perusahaan dari perusahaan keagenan sepeda motor Honda yang berkembang di Jawa Tengah, DIY, Sumatera, Sulawesi, Kalimantan, Ambon, dan Kupang. PT. NSS didirikan pada tahun 2001 sebagai 
main dealerpelumas merek $\mathrm{X}$ untuk area Jawa Tengah dan DIYdengan jaminan rekomendasi dari pabrik.

Sebagai wujud tanggung jawab sosial, perusahaan turut menjaga alam melalui perannya sebagai main dealer pelumas merek $\mathrm{X}$ mengingat pelumas tersebut merupakan pelumas yang ramah lingkungan. Dengan teknologi TVMC, pelumas X mempunyai beberapa keunggulan yang mampu menghemat pemakaian sumber daya alam, seperti teknologi perlindungan mesin yang maksimum, memaksimalkan kinerja mesin, menghemat konsumsi bahan bakar, menghemat biaya perawatan, dan ramah lingkungan.

Pemilik perusahaan merangkap sebagai direktur utama (general manager) yang membawahi seorang manager dan enam salesman. Area pemasarannya terbagi dalam 6 area, yaitu Solo, Jogja, Purwokerto, Tegal, Kudus, Semarang dimana satu area dipegang oleh seorang salesman.

\section{GambaranUmum Responden}

Responden adalah pemilik dari outlet yang tergolong sebagai konsumen aktif, yaitu yang melakukanpembelian secara rutin dalam 6 bulan terakhir.Sebagian besar dari responden berada dalam area distribusi Semarang dan Solo, masing-masing sebanyak $24 \%$ dan $22 \%$ (tabel 3). Berdasar area, responden dari outlet aktif sudah mewakili seluruh area pemasaran PT. NSS dan karenanya penilaian responden juga dapat mewakili kondisi seluruh area.

Tabel 3. Area Responden

\begin{tabular}{clccc}
\hline No. & & Area & Frekuensi & $\%$ \\
\hline \hline 1. & Solo & & 11 & 22 \\
2. & Jogja & 6 & 12 \\
3. & Purwokerto & 8 & 16 \\
4. & Tegal & 5 & 10 \\
5. & Kudus & 8 & 16 \\
6. & Semarang & & 12 & 24 \\
\hline & & Total & 50 & 100 \\
\hline
\end{tabular}


Sumber: Data Primer yang Diolah, 2017

Responden terdistribusi secara relatif merata menurut jenis kelamin, yaitu perempuan 54\% dan laki-laki 46\% (tabel 4). Namun demikian, sebagian besar responden perempuan dan laki-laki berpendidikan S1, masing-masing sebanyak $36 \%$ dan $28 \%$. Dengan tingkat pendidikan S1, maka responden dapat dianggap memiliki kemampuan yang cukup baik untuk memberi penilaian terhadap bauran pemasaran PT. NSS. Dengan pendidikan terendah D3 dan tertinggi S2, responden dapat dipandang mempunyai kemampuan intelektual yang memadai untuk memberikan penilaian.

Tabel 4. Responden Menurut Jenis kelamin dan Pendidikan

\begin{tabular}{|c|c|c|c|c|c|}
\hline \multirow{2}{*}{ Jenis Kelamin } & & \multicolumn{3}{|c|}{ Pendidikan } & \multirow{2}{*}{ Total } \\
\hline & & D3 & $\mathrm{S} 1$ & $\mathrm{~S} 2$ & \\
\hline \multirow{2}{*}{ Laki-Laki } & Total & 5 & 14 & 4 & 23 \\
\hline & $\%$ & 10,0 & 28,0 & 8,0 & 46,0 \\
\hline \multirow{2}{*}{ Perempuan } & Total & 5 & 18 & 4 & 27 \\
\hline & $\%$ & 10,0 & 36,0 & 8,0 & 54,0 \\
\hline \multirow{2}{*}{ Total } & Total & 10 & 32 & 8 & 50 \\
\hline & $\%$ & 20,0 & 64,0 & 16,0 & 100,0 \\
\hline
\end{tabular}

Sumber: Data Primer yang Diolah, 2017

\section{TanggapanRespondenterhadapBauranPemasaran}

Tanggapan responden terhadap tiap elemen bauran pemasaran PT. NSSditunjukkan pada tabel 5. Secara umum, responden menyatakan setuju $(3,83)$ terhadap elemen product, yaitu responden menyatakan setuju bahwa jenis produk yang dijual PT. NSS lengkap $(3,94)$ dan selalu tersedia $(3,72)$. PT. NSS menyediakan semua jenis pelumas yang diproduksi principal dan mencakup seluruh jenis oli yang beredar di pasaran seperti oli matic, oli non matic, oli gear, dan oli racing. Namun demikian, mayoritas responden (52\%) menilai bahwa produk yang disediakan PT. NSS sebagai cukup lengkap. Hanya 6\% yang menyatakan produk tersedia sangat lengkap dan sisanya (42\%) menyatakan sebagai lengkap (lihat tabel 6). 
PT. NSS juga menjaga ketersediaan produk dengan cara menyediakan semua jenis produk principal dalam jumlah yang lebih banyak dari permintaan konsumen. Dengan demikian, jumlah yang diminta konsumen selalu dapat dipenuhi. Tentang hal ini, mayoritas responden (54\%) menyatakan bahwa sebagian besar produk ada/tersedia (tabel 6). Hanya $8 \%$ responden yang menunjukkan keraguan bahwa produk tersedia dengan menyatakan produk 'sepertinya ada.'

Tabel 5. Tanggapan Responden Mengenai Bauran Pemasaran

\begin{tabular}{lc}
\hline \multicolumn{1}{c}{ Item } & Rata-rata \\
\hline \hline Product & $\mathbf{3 , 8 3}$ \\
\hline Jenis produk lengkap & 3,94 \\
\hline Semua jenis produk tersedia & 3,72 \\
\hline Price & $\mathbf{4 , 0 0}$ \\
\hline Harga yang ditawarkan kompetitif & 3,88 \\
\hline Tempo pembayaran piutang dagang cukup & 4,12 \\
\hline Promotion & $\mathbf{3 , 6 6}$ \\
\hline Program promosi menarik & 3,64 \\
\hline Program promosi sering dilakukan & 3,68 \\
\hline Place & $\mathbf{4 , 1 0}$ \\
\hline Pengiriman barang tepat waktu & 3,90 \\
\hline Produk yang diterima konsumen terjamin baik & 4,30
\end{tabular}

Sumber: Data Primer yang Diolah, 2017

Tabel 6. Pernyataan Responden Mengenai Kelengkapan dan Ketersediaan Produk

\begin{tabular}{|c|c|c|}
\hline Pernyataan & Frekuensi & $\%$ \\
\hline \multicolumn{3}{|c|}{ Kelengkapan Produk } \\
\hline Produk cukup lengkap & 26 & 52 \\
\hline Produk lengkap & 21 & 42 \\
\hline Produk sangat lengkap & 3 & 6 \\
\hline TOTAL & 50 & 100 \\
\hline \multicolumn{3}{|c|}{ Ketersediaan Produk } \\
\hline Sebagian besar ada & 27 & 54 \\
\hline Lengkap & 19 & 38 \\
\hline Sepertinya ada & 4 & 8 \\
\hline TOTAL & 50 & 100 \\
\hline
\end{tabular}

Sumber: Data Primer yang Diolah, 2017 
Secara rata-rata, responden juga setuju $(4,00)$ dengan elemen price, yaitu bahwa harga yang ditawarkan PT. NSS kompetitif $(3,88)$ dan tempo pembayaran piutang dagang yang diberikan PT. NSS cukup $(4,12)$. Membandingkan skor ratarata kedua item, dapat dikatakan bahwa walaupun harga kompetitif namun responden lebih memperhatikan tempo pembayaran piutang.

Harga yang diberikan oleh PT. NSS secara umum di bawah harga pasar, Sebagai contoh, harga oli non matic yang dijual oleh perusahaan sebesar Rp25.500/liter yang lebih murah dibanding harga pasar yang sebesar Rp26.000/liter. Namun demikian, masing-masing hanya 22\% dan 28\% responden yang menilai harga PT. NSS murah dan kompetitif (tabel 7). Sebagian responden (50\%) menilai harga sebagai cukup kompetitif.Penetapan harga yang kompetitif merupakan penentapan harga yang didasarkan pada perkiraan tentang bagaimana pesaing akan menetapkan harga, bukan didasarkan pada hubungan yang kaku dengan biaya atau permintaan perusahaan.

Tabel 7. Pernyataan Responden Mengenai Harga dan tempo Pembayaran

\begin{tabular}{lcc}
\hline Pernyataan & Frekuensi & $\%$ \\
\hline \hline Harga murah & Harga Kompetitif & \\
Harga cukup kompetitif & 11 & 22 \\
Harga kompetitif & 25 & 50 \\
\hline TOTAL & 14 & 28 \\
\hline \multicolumn{4}{c}{ Tempo Pembayaran } \\
\hline Tempo pembayaran cukup & 50 & 100 \\
Tempo pembayaran lumayan & 1 & 98 \\
\hline TOTAL & 50 & 2 \\
\hline
\end{tabular}

Sumber: Data Primer yang Diolah, 2017

Tempo pembayaran yang diberikan oleh PT. NSS adalah 3 bulan dimana dalam periode waktu tersebut konsumen telah habis menjual kembali produk yang dibeli sehingga hal ini tidak memberatkan bagi konsumen yang memesan 
kembali. Oleh karena itu, hampir semua responden (98\%) menilai tempo pembayaran yang diberikan perusahaan sebagai cukup.

Besarnya skor rata-rata penilaian responden terhadap elemen promotion adalah 3,66. Artinya responden setuju bahwa program promosi yang dilakukan PT. NSS menarik $(3,64)$ dan sering dilakukan $(3,68)$. Program promosi yang dilakukan perusahaan adalah program berhadiah, yaitu konsumen mendapatkan hadiah tertentu yang nilainya disesuaikan dengan nilai transaksi. Mayoritas responden $(86 \%)$ berpendapat bahwa promosi semacam ini menarik (tabel 8). Namun hanya14\% responden yang menyatakan bahwa promosi banyak. Hal ini berarti bahwa PT. NSS tidak melakukan banyak macam promosi dan promosi yang dilakukan dinilai menarik.

Menariknya promosi yang dilakukan PT. NSS ini mungkin juga terkait dengan frekuensi dilakukannya program promosi tersebut (tabel 8). Sebagian besar responden berpendapat bahwa promosi sering dilakukan (54\%) dan lumayan sering dilakukan $(30 \%)$ dan hanya $10 \%$ responden yang menyatakan promosi tidak begitu sering dilakukan. Hal ini mengindikasikan bahwa PT. NSS sering melakukan program promosi berhadiah walaupun macamnya tidak banyak.

Tabel 8. Pernyataan Responden Mengenai Promosi

\begin{tabular}{|c|c|c|}
\hline Pernyataan & Frekuensi & $\%$ \\
\hline \multicolumn{3}{|c|}{ Kemenarikan Promosi } \\
\hline Promosi menarik & 43 & 86 \\
\hline Promosi banyak & 7 & 14 \\
\hline TOTAL: & 50 & 100 \\
\hline \multicolumn{3}{|c|}{ Seringnya Promosi } \\
\hline Promosi sering & 27 & 54 \\
\hline Promosi lumayan sering & 15 & 30 \\
\hline Promosi cukup sering & 3 & 6 \\
\hline Promosi tidak begitu sering & 5 & 10 \\
\hline TOTAL: & 50 & 100 \\
\hline
\end{tabular}


Sumber: Data Primer yang Diolah, 2017

Dari tabel 5terlihat bahwa elemen place memperoleh skor rata-rata 4,10. Artinya responden setuju terhadap pernyataan-pernyataan tentang distribusi, yaitu bahwa pengiriman barang yang dilakukan PT. NSS tepat waktu $(3,9)$ dan produk yang diterima konsumen terjamin baik $(4,3)$.Waktu pengiriman barang yang dijanjikan perusahaan kepada konsumen adalah 3-6 hari kerja setelah pemesanan diterima dan perusahaan tidak pernah mengirim barang lebih dari waktu yang dijanjikan.

Pernyataan responden tentang hal ini adalah seperti pada tabel 9. Sebagian responden menyatakan bahwa pengiriman barang oleh PT. NSS adalah tepat waktu (30\%), baik (23\%), dan cepat (21\%). Walaupun pernyataan yang digunakan konsumen berbeda, namun dapat dikatakan bahwa ketiganya mengacu pada pengiriman yang tepat waktu. Namun demikian, masih ada responden (17\%) yang menyatakan bahwa pengiriman kadang-kadang mengalami keterlambatan. Hal ini mungkin terkait dengan faktor lokasi.

Secara absolut, semua responden menyatakan bahwa produk yang diterima konsumen terjamin baik (50 responden), namun beberapa responden menyebutkan bahwa produk yang diterima tidak hanya baik tetapi juga tepat (4 responden). Hal ini menunjukkan bahwa PT. NSS dinilai menjaga kondisi produk pada saat pengiriman sehingga barang yang diterima dijamin baik dan tepat. PT. NSS melakukan pengecekan ketat saat barang akan dikirim kepada konsumen sehingga produk yang diterima konsumen dijamin dalam keadaan bersih dan kondisi kemasan barang utuh dan tidak rusak.

Tabel 9. Pernyataan Responden Mengenai Pengiriman Barang

\begin{tabular}{lcc}
\hline Pernyataan & Frekuensi & $\%$ \\
\hline \hline Pengiriman tepat waktu & Ketepatan Waktu Pengiriman & \\
Pengiriman baik & 16 & 30 \\
Pengiriman cepat & 12 & 23 \\
Pengiriman kadang telat & 11 & 21 \\
Pengiriman lumayan baik & 9 & 17 \\
Pengiriman lumayan cepat & 3 & 6 \\
\hline
\end{tabular}




\begin{tabular}{|c|c|c|}
\hline TOTAL: & 53 & 100 \\
\hline \multicolumn{3}{|c|}{ Jaminan Produk } \\
\hline Jaminan produk baik & 50 & 93 \\
\hline Jaminan produk tepat & 4 & 7 \\
\hline TOTAL: & 54 & 100 \\
\hline
\end{tabular}

Sumber: Data Primer yang Diolah, 2017

Membandingkan skor rata-rata tiap elemen bauran pemasaran, diketahui bahwa elemen placememiliki skor rata-rata tertinggi, yaitu sebesar 4,10 (tabel 10). Sebagai perusahaan distributor tentu place merupakan inti dari kegiatan perusahaan.Dengan kata lain, PT. NSS sudah dinilai oleh responden sebagai perusahaan distributor yang baik yang mampu melakukan pengiriman barang yang dipesan secara tepat waktu dan menjaminproduk yang diterima dalam kondisi yang baik.

Sebaliknya, promotion merupakan elemen bauran pemasaran yang dinilai paling rendah dengan skor 3,66. Walaupun program promosi sudah dinilai menarik dan sering, namun dapat dikatakan bahwa promosi kurang signifikan dalam memilih PT. NSS mengingat bahwa perusahaan adalah main dealer untuk area pemasaran tersebut. Status ini menjadi poin promosi tersendiri bagi PT. NSS.

Price yang mendapat skor tertinggi kedua (sebesar 4,00) mengindikasikan bahwa harga merupakan unsur yang dilihat responden untuk membeli dari PT. NSS. Selain harga yang kompetitif, pemberian tempo pembayaran 3 bulan dinilai cukup menguntungkan bagi responden.

Tabel 10. Tanggapan Responden Terhadap Tiap Elemen Bauran Pemasaran

\begin{tabular}{|c|c|}
\hline Elemen & Skor Rata-rata \\
\hline Product & 3,83 \\
\hline Price & 4,00 \\
\hline Place & 4,10 \\
\hline Promotion & 3,66 \\
\hline
\end{tabular}

Sumber: Data Primer yang Diolah, 2017 
Mengingat jenis produk bersifat standar di antara merek-merek yang ada, maka bukan atribut produk yang menjadi pertimbangan dalam membeli, melainkan kelengkapan dan ketersediaan produk.

\section{KESIMPULAN DAN SARAN}

\section{Kesimpulan}

Berdasarkan hasil analisis dapat disimpulkan bahwa kinerja PT. NSS sebagai perusahaan distributor dinilai sudah baik oleh responden, khususnya pada elemen placeyang dinilai paling tinggi dibandingkan dengan elemen lainnya (skor rata-rata tertinggi 4,10). Hal ini mencerminkan bahwa fungsi utama perusahaan distributor yang harus mendistribusikan produk yang dijual secara cepat dan baik oleh PT. NSS telah dirasakan oleh konsumen. Bahkan jaminan bahwa produk diterima dalam keadaan baik merupakan item yang dinilai paling tinggi.

Sebagai main dealer, promotiondan product bukan merupakan elemen bauran pemasaran yang signifikan bagi konsumen. Walaupun sudah dinilai baik merupakan elemen yang dinilai paling rendah dibandingkan dengan elemen lainnya(skor rata-rata berturut-turut 3,66 dan 3,83). Harga merupakan harga standar yang sudah ditetapkan oleh principal, sehingga PT. NSS tidak bisa secara bebas menentukan. Oleh karena itu, tempo pembayaran merupakan hal yang dilihat konsumen dari elemen price.

\section{Implikasi Manajerial}

PT. NSS sebaiknya mempertahankan kinerja dalam pendistribusian barang yang dipesan sehingga barang dikirim tepat waktu dan diterima konsumen dalam kondisi yang baik. Sistem pemesanan yang baik yang mencakup pencatatan pemesanan hingga barang diterima konsumen menjadi penting untuk senantiasa dievaluasi. Sarana transportasi yang memadai baik dalam arti jumlah kendaraan maupun kualitas kendaraan yang mampu mempertahankan kondisi barang dalam keadaan baik menjadi kunci kinerja pendistribusian.

Strategi harga yang dapat dilakukan PT. NSS lebih terkait dengan metode 
pembayaran karena harga sudah ditetapkan oleh principal. Metode lain selain tempo pembayaran 3 bulan yang telah ditawarkan dapat dicari untuk menarik konsumen melakukan pembelian lebih banyak dan sering.

Walaupun promosi bukan merupakan elemen yang signifikan diperhatikan konsumen dalam memilih PT. NSS, tetapi perusahaan dapat membantu program promosi konsumen dalam menjual produknya. Misal dengan memberikan alat bantu promosi seperti leaflet atau brosur yang terkait dengan suatu produk. Dengan cara ini, bila penjualan konsumen meningkat maka pembelian produk ke PT. NSS juga akan meningkat.

\section{DAFTAR PUSTAKA}

Amna. (2014). Strategi Bauran Pemasaran (4P) Terhadap Tandan Buah Segar (TBS) Kelapa Sawit Pada PT. MarihatTambusai. Jurnal Manajemen .

Azwar, S. (2000). Reliabilitas dan Validitas, Edisi 3. Yogyakarta: Pustaka Pelajar.

Fayshal, A., \& Medyawati, H. (2013). Analisis Strategi Pemasaran Produk Asuransi Jiwa Pada Bumi Putera Syariah Cabang Depok. Jurnal Asuransi dan Manjemen Resiko, 1(2).

Ghozali, I. (2013). Aplikasi Analisis Multivariate dengan Program SPSS. Eisi Ketujuh. Semarang: Badan Penerbit Universitas Diponegoro.

Jaakkola, M., Möller, K., Parvinen, P., \& Evanschitzky, H. (2012). Strategic Marketing and Business Performance: A Study in Three European Engineering Countries. International Journal of Research in Marketing .

Kotler, P. (2001). Marketing Management. New York: Prentice Hall.

Mongay, J. (2006). Strategic Marketing. A Literature Review on Definitions, Concepts and Boundaries. MRPA Paper No.41840 .

Sugiyono. (2014). Metode Penelitian Pendidikan Bisnis. Bandung: CV Alfabeta.

Vignali, C. (2001). McDonald's: "Think Global, Act Local" - The Marketing Mix. British Food Journal , 103(2), 97-111.

Wibowo, H., Arifin, Z., \& Sunarti. (2015). Analisis Strategi Pemasaran Untuk Meningkatkan Daya Saing UMKM (Studi pada Batik Diajeng Solo). Jurnal Administrasi Bisnis , 29 (1). 